\title{
Abraham's Trials in Ancient and Medieval Jewish Writings
}

\author{
KATARZYNA MIRIAM KACZOROWSKA \\ Christian Theological Academy in Warsaw \\ katarzyna.kaczorowski@gmail.com, ORCID: 0000-0002-8742-2657
}

\begin{abstract}
The article presents a brief overview of the Jewish rabbinical resources with regard to the $\mathrm{Pa}$ triarch Abraham and his life, viewed as a series of trials. From the second century BCE, the Jewish authors were recognizing numerous events in Abraham's life as ordeals, gradually more and more difficult and challenging. Through them God put Abraham and his faith to the test in order to assure that his election of Abraham was right. On the basis of The Book of Jubilees and several rabbinical works, including Pirqe Abot, Pirqe Rabbi Eliezer and Abot de Rabbi Nathan as well as the writings of Jewish medieval commentators (esp. Maimonides and Rashi), the paper in detail analyzes the concept of these trials and the differences that can be identified in the sources concerning their identification and order. Firstly, the reasons of the rabbinical commentators' particular interest paid to Abraham have been given. Subsequently, the concept of his numerous trials, identified by the rabbis and Jewish scholars, have been discussed, followed by a thorough presentation of selected rabbinic works and discussions whether the experiences of Abraham's life should and/or should not be regarded as trials.
\end{abstract}

Keywords: Abraham's trials, Pirqe De Rabbi Eliezer, Bereshit Rabbah, Genesis Rabbah, Book of Jubilees, rabbinical commentaries, Abot De Rabbi Nathan, Akedah, Pirqe Abot

Abraham is a key figure in the collective memory of Israel. He is regarded as the forefather, the progenitor of the entire Israel and the role model to follow with respect to his deeds and character. It was also through Abraham that the idea of the Promised Land, or a homeland for the Jewish people, was created. Judaism - differently from the Christian tradition which recognizes the binding of Isaac on Mountain Moriah (Hebr. akedah, "binding") as a sole and single trial - perceives his entire life as a series of trials purposed for confirming his unusual character and unshakable faith in One God. By analyzing Abraham's life and experiences the rabbis proved the power of Abraham's faith and the confidence of the way he was experiencing it, which, for believers may become a perfect example to follow.

Akedah, the ultimate test of Abraham's obedience, is one of the most famous and most powerful narratives in the Hebrew Bible. At the same time, it is also a shattering account of devotion to God against all odds, an example of unlimited and unconditional faith and trust. In the Jewish tradition it is, however, just one of many trials which served the Almighty for examining the character and devotion of the Patriarch, 
the last one. The rabbis are neither uniform as to which events constitute trials or what was their order and reasons. Thus, the purpose of this article is to present Jewish interpretations of Abraham's life as a series of challenges, given by the Almighty to the Patriarch, and to describe briefly which events of his life the Jewish tradition identifies as trials and whether there is one or many "lists" of such trials.

For the purpose of this study, numerous Jewish traditional sources referring to the trials of Abraham have been analyzed. Among many commentaries to the Torah, primarily Pirqe Abot ( $m$. Pirqe Abot) has been taken into consideration. Further, Midrash Bereshit Rabbah (Gen. Rab.) and Pirqe Rabbi Eliezer (Pirqe R. El.), essential in this respect, have been reviewed, as well as 'Abot de Rabbi Nathan ('Abot R. Nat.). The apocryphal Book of Jubilees, which in its contents follows the path of Abraham's life, but does not comment on his character, has also to be indicated among our primary sources, as numerous historical details regarding the life of Abraham prior to his departure to Canaan can be found there. Reference will also be made to some later rabbinical commentaries (e.g. Maimonides, Rashi) on the trials.

\section{Jewish Sages and Rabbis' Reasons for Their Particular Analyses of Abraham's Life}

Neither the reasons for God's election of Abraham or the detailed description of the trials Abraham passed can directly be found on the pages of the Torah. They can, however, be recovered from the Jewish tradition, including the rabbinical interpretation of Abraham's life. Due to the key importance of Abraham in the Jewish tradition (he is regarded as the Patriarch, Forefather and Founder of the Nation), his life and personality must have attracted the rabbis' attention and became targeted by their analyses and commentaries. The Torah itself and its certain features were definitely the factors that caused their particular interest. Namely, what the rabbis underline is that the Torah itself distinguishes the importance of particular characters by way of providing more and/or less interest (and verses) to the given person. For example, the Torah was not particularly interested in the idol-worshipper Terah or in the issues related to the lives of the other descendants of Shem, but only in the prospective importance of Abraham for the Nation of Israel and all humanity. Judaism interprets the fact that Abraham was chosen by God and subsequently successfully passed ten trials as proof of Divine infallibility. Therefore, his life was described in detail and that was the first hint for the rabbis to further, meticulously analyze it. They were looking for events in Abraham's life, by which God assured himself in his choice and Abraham's faith and dedication was getting stronger and unconditional - events that were "forging" Abraham as a prospective Father of Israel. 
Another explanation for the reasons why the rabbis scrutinized Abraham's life can be the use of the rare word and/or words, which in similar context is not used anywhere else in the Hebrew Bible. The rabbis explain that the Torah itself attracts the attention of those who study it through some words used incidentally, encouraging, in such a way, for a more detailed and perceptive study. ${ }^{1}$ In case of Abraham, the rabbis turned their particular attention to Gen 22:1, and the word (nissa, "to put to the test"), which in this specific form (Piel, third person, masculine, singular) appears exclusively in this verse. Its uniqueness drew attention and intrigued the rabbis.

Also, gematria, i.e. the specific Hebrew numerology, one of the hermeneutical methods of explaining texts, could be the reason for a search of ten special, particular events in Abraham's life, which could be classified as characterological trials increasing the power of Abraham's authority and the respect paid to him. Thus, the numerological analysis may also have attracted the rabbis and caused their further complex analysis of Abraham's life as described in the Torah as well as the numerological considerations related to the particular events in the Patriarch's life. Such numerical devices can be observed with respect to Abraham and the events that the rabbis interpreted as trials. ${ }^{2}$ They noted that the particular events in Abraham's life corresponded with the numbers having specific meaning for the Jewish theology, such as seven or ten. Number ten with respect to the assumed number of the Patriarch's trials is analogous to the ten Egyptian plagues (Exod 7-12). The similarity does not regard only number ten as such but also the story hidden in this number (as well as in number seven). In both cases, it is connected with death. Some more detailed considerations will be made with respect to the seventh and tenth trials. It can therefore be assumed that the numerological analysis motivated the rabbis to examine the events in Abraham's life, which could be qualified as characterological tests asserting the Patriarch's authority.

\section{A Trial or Trials?}

In accordance with the long-lasting Jewish tradition, Abraham was put to a number of trials. Generally ten trials are mentioned, and there is a common understanding

1 In the commentary contained in petiha 53:9 to Gen Rab, rabbi Pinchas on behalf of rabbi Helkiah questions why in Gen 21:7 the very rare word מִ (meaning "state, say") was used and explains that it is the Torah that gives a self-explanation, providing (using such specific and/or rare words) guidelines and hints for a more detailed analysis.

2 This specific methodology has been noticed among others by Scott B. Noegel ("Abraham's Ten Trials," 74), who pointed out to such tools as the seven-and-ten device. Following Gary Redensburg's view, Noegel saw that "in the Bible where rosters of ten occur, special prominence is given to the entries listed in the seventh and tenth position." For that reason particular focus and detailed analysis was given to the events of Abraham's life which were listed as seventh and tenth (in line with Pirqe R. El. these are the Covenant Bein HaBetarim and Akedah). 
for the recognition of their multitude (and not just a single "trial"). It is already directly referred to in the $m$. Pirqe Abot $(5,3)$, which dates back to the 2 nd century BCE, ${ }^{3}$ the text was later included into the Mishnah, ${ }^{4}$ as well as in 'Abot R. Nat. (33,1-2). ${ }^{5}$ A full list of trials is provided by Pirqe R. El. and other rabbinical sources. It was later repeated in various configurations by such distinguished commentators as Maimonides (Rambam), Nahmanides (Ramban) and Rashi.

The number of trials, which Abraham passed, has been counted and/or classified by the rabbis in various ways. As 'Abot $R$. Nat. $(33,2)$ already notices, some can be paired, i.e. it can be stated that two of the trials regard the order to get underway (Gen 12:1-2; 12:10), two trials regard Abraham's sons (Gen 21:10; 22:1-2), and there are two trials related to his two wives (Gen 12:11-12; 21:10). There are also several "single" trials, such as the war with the kings (Gen 14), the unique trial regarding the Covenant of the Parts (Gen 15), also a single trial, when Abraham was thrown by Nimrod to the furnace in Ur Khasdim (this event is not mentioned in the Hebrew Bible, but it is repetitiously mentioned in the midrashim ${ }^{6}$ ) and just one trial of circumcision (Gen 17). 'Abot R. Nat. (33:2) explains that there were so many trials, because:

So that when Abraham our father comes to take his reward, the peoples of the world shall say: "More than all of us, more than everyone, is Abraham worthy of getting his reward!" And it is of him that Scripture says, Go thy way, eat thy bread with joy, and drink thy wine with a merry heart, for God has already accepted thy works. (Eccl. 9:7). ${ }^{7}$

Some rabbis take also notice of the relationship between Abraham's trials and God's ten creative pronouncements (Gen 1:1-28), through which the world was

3 The rabbis who compiled $m$. Pirqe Abot lived in the centuries around the beginning of the Common Era, however, due to the fact that $m$. Pirqe Abot contains sayings attributed to sages from Simon the Just who lived around $200 \mathrm{BCE}$ it is believed that $m$. Pirqe Abot started originating in the 2nd century BC and was later compiled and included into the Mishnah.

4 The Mishnah is the first major work of rabbinic literature, consisting of teachings transmitted over hundreds of years and finally compiled around 200 CE. It is a foundation of the Jewish oral tradition developed over several prior centuries and codified after the fall of the Temple, which continues with the Talmud, a work that is structured as a commentary on the Mishnah.

5 'Abot de Rabbi Nathan ("Fathers of Rabbi Nathan") is a companion volume to m. Pirqe Abot, presenting maxims of wisdom alongside explanations and stories. Dated to the 7th-9th centuries CE. The work has come down to us in two highly different versions, customarily termed Version A (40 chapters) and B (49 chapters).

6 It is also referred to in the non-rabbinic ancient work, i.e. Pseudo-Philo's Liber Antiquitatum Biblicarum, 6,16, in Jacobson, A Commentary, 10.

7 Goldin, The Fathers, 132. The translation of 'Abot R. Nat. (version B) by Anthony Saldarini (The Fathers, 214) contains a different text which goes as follows: "What is the purpose of this for all the inhabitants of the world? This is to teach you that when Abraham our Father, may he rest in peace, comes to receive his reward, the inhabitants of the world will say: More worthy than (all who are) here is Abraham to receive (his reward)." 
made. Abraham experienced ten trials and passed all of them successfully, proving that he was worthy of sustaining the world created by these ten pronouncements.

Abraham's experiences should not be perceived as separate from one another. They all constitute one path, scheduled by the Eternal, which shapes Abraham's moral and spiritual development. Through the covenants with God and successfully passing the tests, Abraham became the first human being to reject false gods in favor of the one true God. Jews believe that the covenants between God and Abraham extend to all Jewish people. It was the start of the relationship between God and the Nation of Israel.

The midrashim and rabbinical commentaries differ between themselves with respect to which events in the life of Abraham should be regarded as trials and what their order was. They, however, are almost unanimous (with one single exception contained in Jub.) in viewing Akedah - the binding of Isaac and his offering at Mount Moriah as the last, tenth trial. They differ as to when putting Abraham to test started. For example, in line with the account provided in Pirqe R. El. (below in more detail) Abraham passed his two initial tests yet before receiving God's call to leave Haran. The call to go forth from Haran and set out to Canaan with Sarah and Lot was only the third trial. On the other hand, some midrashim as well as such contemporary American researchers as Israel Drazin and Stanley Wagner (describing the views of the rabbis in their study to Targum Onkelos) indicate that the first of Abraham's trials took place in Gen 12:1, when Abraham without any hesitation with respect to God's call lech-lecha (†? "go "go for yourself") ${ }^{8}$ agreed to leave his family house in Haran and took the journey into unknown. They indicated, referring to later commentators, two possible ways of interpreting the "trials." In the first option (according to Nahmanides, Abraham ibn Ezra and Judah Halevi), God knew how Abraham would react but still intended to unleash his potential and increase it for the sake of self-consciousness. In line with the second view (according to David Kimhi, Chazkunee and Maimonides), the story of Abraham's trials was told in order to teach us, but not Abraham, how to live our lives. The Rabbis, quoting God's words spoken to Abraham lech lecha, were of the view that the Eternal must already have checked in some particular way the Abraham's "righteousness." Thus, they strove to identify them in Genesis and analyze them in detail. The Torah does not contain this information, the search should be carried out in the commentaries and rabbinic studies. Below the detailed orders of the trials according to several, below-referred sources will be presented.

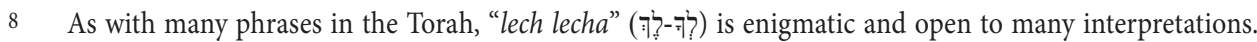
It is understood as "Go to yourself," an internal odyssey. It has also been translated as "Get you out, Go for yourself, Go forth, Go out." That is to say, disassociate from where you are; a call with an external echo to it.

9 Detailed commentary on theological sense of the trials, in particular Akedah: Drazin - Wagner, Onkelos, 132-137. 


\section{Ancient and Medieval Rabbinic Writings}

\subsection{Pirqe Abot}

Pirqe Abot, originated around the 2nd century BCE, later included into the Mishnah, is the oldest rabbinic work where the ten trials are explicitly mentioned. Pirqe Abot $(5,4)$ indicates that "for ten trials Abraham, our Father, was put, and all he passed through, this shows the love of Abraham, our Forefather, [to God]," but it does not specify which these tests were. ${ }^{10}$ Pirqe Abot stresses the importance of number ten, indicating, e.g. "ten utterances" of the world's creation, ten generations from Adam to Noah and then another ten from Noah do Abraham, ten trials of Abraham, and later ten miracles and ten plagues in Egypt. Consequently, the rabbis wanted to emphasize Abraham's uniqueness and importance. One of the later commentators of Pirqe Abot, rabbeinu Yonah Gerondi (d. 1264) specifically lists these tests, indicating the fiery furnace of Nimrod as the first one, lech lecha as the second, then departure to Egypt, taking Sarah to Pharaoh, the war of kings as the fifth, then the circumcision, taking Sarah to Abimelech, sending away Hagar and Ishmael, Akedah (which is the ninth on this list) and the burial of Sarah as the tenth and last one. They are, however, not listed in $m$. Pirqe Abot itself. Only the later rabbinic works provide more detailed lists.

\subsection{The Book of Jubilees}

The Book of Jubilees is a pseudepigraphic work dating back to the times of the Second Temple, in the 2nd century BCE. ${ }^{11}$ According to the tradition it is a secret revelation of the angel of "Divine Presence" to Moses during his second Ascend to Mount Sinai (it is therefore also called the Testament of Moses and/or Moses' Apocalypse). Chapters 11-22 refer to the story of Abraham. There are only two verses in the entire description that refer to the trials of Abraham, including one verse listing specifically six of these trials through which God tested the Patriarch's character and faith. In $J u b .17: 17$, the following description can be found:

Now the Lord was aware that Abraham was faithful in every difficulty which he had told him. For he had tested him through his land and the famine; he had tested him through the wealth of kings; he had tested him again through his wife when she was taken forcibly, and through circumcision; and he had tested him through Ishmael and his servant girl Hagar when he sent them away. ${ }^{12}$

10 My own translation of the traditional Hebrew text in Pecaric, Sidur Pardes Lauder, 579. According to R. Travers Herford's translation ("Pirke Aboth: The Sayings of the Fathers," 707): "Ten trials Abraham our father was tried with, and he bore them all, to make known how great was the love of Abraham our father."

11 Y.M. Grintz, "Jubilees, Book of," EncJud XI, 473.

12 VanderKam, Jubilees, I, 551. 
Further, there is a supplementary description: "In everything through which he tested him he was found faithful. He himself did not grow impatient, nor was he slow to act; for he was faithful and one who loved the Lord" (17:18). ${ }^{13}$

Having analyzed the above-referred part of Jubilees it is possible to identify six of the ten trials mentioned in the Abraham's story in Pirqe R. El. The Book of Jubilees mentions the promised land - Canaan - it probably refers to the commandment of departing from Haran and setting off to Canaan (Jub. 12:22), famine and departing to Egypt (Jub. 13:10), Abraham's wealth obtained from the kings (Jub. 13:28-29). The subsequent trials are the case when the wife of Abraham (Sarah) was taken by force from him by Pharaoh (Jub. 13:13-15), the circumcision of Abraham and all of his family and servants (Jub. 15:23-24) and the casting out of Ishmael and Hagar (Jub. 17:4-8). As it can clearly be seen, Jubilees also does not list all the trials, but it confirms the majority of them. It also confirms the accepted total number of trials as further, in 19:8, it explicitly mentions the tenth test: untypically, Jubilees regards as such not the Akedah of Isaac (this story is discussed in the preceding chapter 18) but the death of Sarah and Abraham's efforts to purchase the Machpelah Cave. Jubilees explicitly states that that was the last test of Abraham: "This was the tenth test by which Abraham was tried, and he was found to be faithful and patient in spirit."14 Thus, already an early Jewish tradition, preserved in Jubilees, confirms the common belief present in the Second Temple times regarding the ten trials. Their specification, however, differs in details from the interpretation preserved in later texts.

\subsection{Pirqe Rabbi Eliezer}

Pirqe de Rabbi Eliezer is a midrash that retells and expands upon the stories of the Torah, from the creation of the world through the story of Miriam's leprosy. Pirqe R.El. contains the fullest description of Abraham's trials, including the last one (in accordance with this source text) that took place on Mount Moriah. Pirqe R. El. is obviously not the only Jewish text, where the trials of Abraham are referred to. Still, Pirqe R. El. is very extensive and due to its broad contents and complexity it is a particularly valuable source for our analysis. Its principal redaction dates back to the 8 th century $\mathrm{CE},{ }^{15}$ and it was made almost right after the final redaction of Talmudim had been completed, which suggests that it can use some

\footnotetext{
13 VanderKam, Jubilees, I, 551.
}

14 VanderKam, Jubilees, I, 583.

15 The redaction of the text is estimated for the period of the 8th-9th centuries, but it contains a much earlier tradition (Stemberger, Introduction, 131-159). Stemberger states that "the work appears to have originated in the eighth or ninth century" [it seems that it is already quoted in the early ninth century by Pirqoi ben Baboi] (Stemberger, Introduction, 329). 
additional portion of knowledge that is not yet contained, e.g., in the Gen. Rab. ${ }^{16}$ Pirqe R. El. makes referrals to the Babylonian Talmud, however, it originated probably in Palestine, as the majority of rabbis quotes come therefrom, and it uses the descriptions of Abraham's story from other rabbinical sources. Below a detailed list of the ten trials based on the account provided in the Pirqe R. El. has been presented.

The first trial was the trial of salvation - survival of Abraham - and it was directly connected with his birth. ${ }^{17}$ On that day a new star appeared in the skies. King Nimrod's magicians noticed that and concluded that the person who had just been born, would become a significant threat to Nimrod. That is why they intended to kill him. From the contents of Jub. (complementary to Pirqe R. El. in this context), it is known that Nimrod had all male new-borns killed in the year when Abraham was born. Terah hid Abraham in the cave and kept him in hiding for 13 years. When Abraham left the cave, he was speaking the language of God - the language of the first settlers after the Flood, before the Eternal mixed the languages. ${ }^{18}$ During the time of hiding, Abraham got to know the Eternal and despised all the Nimrod's idols and gods. Pirqe R. El. quotes Ps 84:11: "For God is a sun and shield: the LORD will give grace and glory: no good thing will he withhold from them that walk uprightly."

The second trial occurred after leaving the cave, when Abraham was serving his father at home. ${ }^{19}$ Abraham destroyed the idols and Terah handed him over to Nimrod and brought to court. He was sentenced to prison, where he spent ten years: three years in Kuthi and seven years in Budri. Here rabbinic numerology indicates important numbers, including " 7 " and "10." The seventh Egyptian plague (Exod 9:25) and the tenth plague (Exod 12:29-30) were associated with death. Abraham spent ten years imprisoned and was also near to death: right there in the end of his captivity by order of Nimrod (b. B. Bat. 91a) he was thrown into the furnace. But the King of Glory raised His right hand and extracted Abraham from the furnace and said to him, paraphrasing the verse from Gen 15:7 ("I am the LORD that brought thee out of Ur of the Chaldees"20): "I am the Lord that brought thee out of the furnace" [Nimrod's]. It is worth noting that the Hebrew expression (Ur) also in Babylon used to be associated with fire and furnace - therefore the rabbis note Abraham lived in Babylon: Ur Khasdim (Ur of the Chaldees) - the place where Terah settled with his family.

16 Günter Stemberger (Introduction, 329) concludes that "it uses a wealth of older tradition and shows itself aware of the pseudepigrapha; it may also have adopted entire chapters from other sources, almost without alteration."

17 Friedlander, Pirkê, 187-188.

18 Gen. Rab. 42:8, b. Sotah 12a.

19 Friedlander, Pirkê, 188.

20 The biblical quotations from the King James Bible, if not indicated otherwise. 
The third trial according to the rabbis is Abraham's migration from Haran to Canaan (the lech lecha trial). ${ }^{21}$ As stated in Pirqe R. El., Abraham's father Terah and his mother Athrai died long after Abraham left Haran, Terah in the year 2082 from Adam's times, and the date of the death of Abraham's mother is not provided. Pirqe R. El. points out that migration is the most difficult decision for every human being, far more than for any other creature (b. Ketub. 28b), based on Isa 22:17: "Behold, the LORD will carry thee away with a mighty captivity, and will surely cover thee."

The fourth trial was, as it is provided in Pirqe R. El., the famine in the land of Abraham in Canaan. ${ }^{22}$ Pirqe R. El. notes that it is the first famine since the Flood which is contrary to the account provided by the rabbis in the Gen. Rab. where two famines are mentioned prior to the times of Abraham. Rashi, in his commentary, indicates that famine and draught occurred in Canaan only in order to force Abraham to journey to Egypt, which was the closest neighboring country.

The fifth trial took place when Sarah, Abraham's wife, was taken away from Abraham and brought to Pharaoh to become his wife. ${ }^{23}$ Abraham did not object that, because he believed that God would save Sarah and himself. Rabbi Joshua ben Korchah (in some other versions of Pirqe R. El.: rabbi Tarphon) indicates that Sarah was taken to Pharaoh on the day of Pesach (it was the Passover night, and the Holy One, blessed be He, brought upon Pharaoh and upon his house great plagues, to make known that thus in the future would He smite the people of his land, as it is said). Once Sarah was brought to the court, the marriage ceremony was carried out and the marriage document was written down. Pharaoh promised in this document that in case of divorce (upon issuing get) Sarah would be provided with wealth, including gold, silver, servants and land in Goshen. Immediately after the ceremony, God punished Pharaoh and his servants with disease and plagues (Gen 12:17). Both Pharaoh and his servants were afflicted with impotence, and the monarch could not consume his marriage with Sarah. This sign from God received by Pharaoh was prophetic, as by way of that Pharaoh learned from the Highest that he could not consume this marriage nor have any children. God provided Pharaoh with the information that the descendants of Abraham would return (to the Land of Goshen) and the Almighty would strike Egypt stronger and lethally once again. Where does this information come from? In Exod 11:1, it is written that "Yet will I bring one plague more upon Pharaoh, and upon Egypt." Thus, Pharaoh freed Sarah providing her with a divorce letter and as a "severance pay" he gave her a significant property, including the Land in Goshen, where the Israelites later were enslaved. This is the account from which we learn about

21 Friedlander, Pirkê, 188.

22 Friedlander, Pirkê, 189.

23 Friedlander, Pirkê, 189-190. 
the gift of Pharaoh who gave Sarah his own daughter Hagar (Gen. Rab. 45,1), ${ }^{24}$ born from a concubine, as her handmaid. ${ }^{25}$ Abraham and Sarah left Egypt with their entire family and went to the land of the Philistines to rest. ${ }^{26} \mathrm{~A}$ similar story happens again later with king Abimelech (b. B. Qam. 92a), who similarly to Pharaoh experienced impotence - thanks to another God's intervention Abraham and Sarah become wealthy.

The sixth trial, was the victory of Abraham over the four kings (Gen 14:1-16), "(when) all the kings came against him to slay him." ${ }^{27}$ Thanks to God's intervention and help, Abraham and his $318^{28}$ armed and trained servants fought off the attack of the four kings and released many people from slavery, Lot, Abraham's nephew, included. Amraphael, also called Nimrod (b. Erub. 53a; Gen. Rab. 52,4) ${ }^{29}$ was defeated by Abraham and Eliezer during the "mid-night," ${ }^{30}$ when the Angel of Death passed and killed all the firstborns. Pirqe R. El. reports that thanks to his victory Abraham won great wealth (according to the account of Hillel the Elder) and as the first one provided a tithe to Shem, son of Noah (Abraham was the first to begin to give a tithe. He took all the tithe of the kings and all the tithe of the wealth of Lot, the son of his brother, and gave (it) to Shem, the son of Noah, as it is said, "And he gave him a tenth of all"). Also, in this midrashic text there is no direct mention of king Melchizedek, however, in this respect Pirqe R. El. is conform (in the footnotes) that Shem shall be identified with Melchizedek (Jub. 13:25). ${ }^{31}$ As said by Pirqe R. El. Abraham praises God: "Sovereign of all worlds! Not by the power of my hand, nor by the power of my right hand have I done all these things, but by the power of Thy right hand with which Thou dost shield me in this world and in the world to come, as it is said" and later he quotes Ps 3:3: "But thou, O Lord, art a shield about me."32

The seventh trial is the Covenant of the Parts - Brit Bein HaBetharim (Gen 15:1-18). ${ }^{33}$ In this seventh trial, Abraham experienced one of the most significant covenants with God, as it was the covenant unto "life and death." It has to be mentioned that the interpretation of the "flaming torch" (smoking furnace) in

24 Freedman - Simon, “The Midrash," 379.

25 Vanderkam, Jubilees, II, 464.

26 Friedlander, Pirkê, 191.

27 Friedlander, Pirkê, 193-196.

28 Some rabbis indicate that there are numerological issues also in this case: Abraham's chief servant, Eliezer, and described as his sole heir in Gen 15:2, has a Hebrew name that adds up to 318.

29 Freedman - Simon, "The Midrash," 451.

30 There is a similarity here to the description of Exodus from Egypt, which also happened during the "midnight" (Exod 12:29). See Gen. Rab. 43,3 (Freedman - Simon, “The Midrash," 352).

31 The direct indication that Shem is Melchizedek is made in the footnote 3 to Gen. Rab. 44,7 (Freedman Simon, "The Midrash," 364), where it is explained that "Shem is identified with Melchizedek." Such identification is also made in Louis Ginzberg (Legends, 233) following the text of Book of Jasher 16,11 (Lumpkin, Encyclopaedia, 255).

32 Friedlander, Pirkê, 196.

33 Friedlander, Pirkê, 197-202. 
Gen 15:17, passing between the pieces of animals was interpreted by rabbi Ze'er (most likely Azariah) with use of an example taken from Isa 31:9 ("the LORD, whose fire is in Zion, and his furnace in Jerusalem"), which suggests the constant presence of God in Jerusalem. It is also indicated that Isaiah, as well as probably other prophets believed in the power of the eternal covenant Brit Bein HaBetarim, whose time, duration and validity have no end date - it remains in force until the times of the coming of King Messiah.

The eight trial ${ }^{34}$ occurred when Abraham was 99 years old and performed the rite of Brit Milah (Gen 17:24-27), i.e. the circumcision of the foreskin flesh of himself, Ishmael and all the male servants on the day of Yom Kippur, the seventh day of the month Tishri (Gen 17:23; Gen. Rab. 46:4; 47:8). ${ }^{35}$ Other sources provide that it took place on Rosh HaShana or over during the Passover time (b. B. Mes. 86b, Jub. 34:18). Pirqe R. El. quotes in this respect the phrase from Isa 52:1: "put on thy beautiful garments, $O$ Jerusalem, the holy city: for henceforth there shall no more come into thee the uncircumcised and the unclean." It also explains that:

the foreskin is a reproach, as it is said, "For that is a reproach unto us" (Gen 34:14), because the foreskin is more unclean than all unclean things, as it is said, "For henceforth there shall no more come into thee the uncircumcised and the unclean" (Is. 52:1). For the foreskin is a blemish above all blemishes. Circumcise the flesh of thy foreskin and be perfect. ${ }^{36}$

According to one of the many Jewish traditions, as presented in Pirqe R. El., the circumcision of Abraham was performed by Shem, the son of Noah. Rabban Gamaliel - the son of Rabbi Jehudah HaNasi (the Prince) - said in Pirqe R. El. 29:2: "Abraham sent and called for Shem, the son of Noah"37 (who was born circumcised) for to perform the rite of Brit Milah - the circumcision of Abraham, Ishmael and the male servants. It has to be explained that in the rabbinic tradition (it is accounted for in detail in the Gen. Rab.), the long-lived Shem is identical with the biblical king of Salem (Jerusalem), called Melchizedek - the Righteous King. It may be asked: if Shem were circumcised and knew the Brit Milah rite, opening the gates of God's blessings, why had he waited until that time to convince Abraham? Abraham had been living in Canaan for 24 years then. Until his circumcision in the year 2039, there were numerous other Shem's relatives still alive, not only Shem himself, but also Serug (d. in 2049), Arpachshad (d. in 2096), Shelah (d. in 2126) and Eber as the last of Shem's lineage

\footnotetext{
Friedlander, Pirkê, 203-214.

Friedlander, Pirkê, 204.

Friedlander, Pirkê, 203.

Friedlander, Pirkê, 203.
} 
(d. in 2187). Gen. Rab. does not mention Shem as the mohel circumcising Abraham and his entire male family, and yet it originated before Pirqe R. El. Thus, it may be assumed that the story of Abraham's circumcision by Shem as it is provided in Pirqe R. $E l$ is a work of fiction, and such a mention of him performing the rite was supposed to highlight the significance and importance of the rite itself. In Pirqe R. El. 29,2, as rabbi Gamaliel reports, the rite took place: "In the selfsame day which (means) in the might of the sun at midday [...] All those, who were circumcised had (excessive) pain on the third day, as it is said, «And it came to pass on the third day, when they were sore»" ${ }^{38}$ On the third day following circumcision, when Abraham was still very sore (Gen 34:25), he met God and His ministering angels (Gen 18:1): "The Holy One, blessed be He, and the angels descended to visit our father Abraham, as it is said, "And the Lord appeared unto him»" 39

The ninth trial, in accordance with Pirqe R. El., regards Abraham's decision to cast out Hagar and Ishmael (Gen 21,12-14). ${ }^{40}$ Ishmael was 17 at that time (according to Venice manuscript of Pirqe R. El. he was 27). ${ }^{41}$ The account contained in Pirqe R. El. clearly confirms that Hagar was Abraham's wife, and not just a handmaid or servant, as Abraham wrote her a bill of divorce and gave her bread and water:

he sent her and her son away from himself, and from Isaac his son, from this world and from the world to come, as it is said: "and Abraham rose up early in the morning, and took bread and a bottle of water" (Gen 21:14). He sent her away with a bill of divorcement, and he took the veil, and he bound it around her waist, so that it should drag behind her to disclose (the fact) that she was a bondwoman. ${ }^{42}$

Since the divorce occurred by Hagar's fault, she was not entitled to any severance, such as in the case of Sarah being sent away by Pharaoh or by Abimelech. Further, there is information that following Sarah's death Abraham found Hagar and remarried her as his third wife. ${ }^{43}$ She was then called Keturah - "fragrance, incense":

38 Friedlander, Pirkêe, 204

39 Friedlander, Pirḳ̂, 205.

40 Friedlander, Pirkê, 203-214.

41 Friedlander, Pirḳe, 216.

42 Friedlander, Pirkê, 216.

43 The Tannaim disagree about Keturah's identity. According to one view, Abraham remarried after Sarah's death and had a total of three wives: Sarah, Hagar, and Keturah. Another tradition identifies Keturah with Hagar, and thus Abraham married only twice. Rashi boldly suggests that Keturah is Hagar: "She was called Keturah because her deeds were as pleasing as incense and because she tied up her opening [explanations emerging from two rabbinic folk etymologies on her name]; from the day she left Abraham, she did not couple with any man." Targum Yonatan, an Aramaic translation/commentary that is attributed to Yonatan ben Uziel, makes an even stronger statement to suggest that she was Hagar: "She was Hagar, who was bound to him from the start." 
after the death of Sarah, Abraham again took (Hagar) his divorced (wife), as it is said, "And Abraham again took a wife, and her name was Keturah" (Gen 25:1). Why does it say "And he again"? Because on the first occasion she was his wife, and he again betook himself to her. Her name was Keturah, because she was perfumed with all kinds of scents. ${ }^{44}$

God approved this trial because Ishmael and Isaac's lives would collide both with the prospective of God's plans, as well as with Abraham's own expectations.

The tenth trial, being the climax of Abraham's experiences, was the binding (Akedah) of Isaac (Gen 22:1-16) on Mount Moriah (identified with Mount Zion, and sometimes called Zophim "watchers"). ${ }^{45}$ The account provided in Pirqe R. El. is basically consistent with the Gen. Rab., except for the fact that (due to the time of its redaction) different rabbis make comments and participate in the debate. Rabbi Zechariah indicates that the ram offering on Mount Moriah took place exactly at twilight on a Shabbat.

The outcome of Akedah was the confirmation that Abraham was able to offer any sacrifice to God, including his son Isaac. The commentary in Pirqe R. El. enables us to empathize with Abraham's concerns, pleading God not to put him [Abraham] on any more trials, as the last one was the most difficult and terrifying of them all.

The rabbis in Pirqe R. El. infer from the description of Akedah that all the blessings from God always come for the "merit of prayer." Rabbi Isaac quotes Gen 22:5: "Abide ye here with the ass; and I and the lad will go yonder and worship

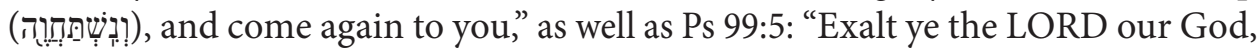

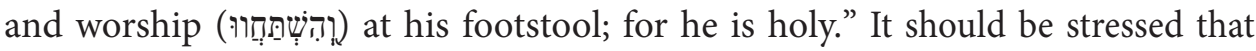
none of the translations ("to worship," "to bow oneself") fully reflect the profundity and the actual sense of the original word. The Hebrew verb חוה in Hishtaphel has yet a deeper meaning, emphasizing specific humility, humbleness and servitude with respect to the authority and power of the Almighty. ${ }^{46}$

The list of the trials, as presented above in line with the contents of Pirqe R. El., has been fully and without any alterations accepted by Rashi. On the other hand, some scholars such as Maimonides and Joseph Hayyun (in Millei de-Abot, the commentary to Pirqe R. El.) modify this description. Maimonides in his commentary to the Mishnah lists the trials as follows:

\footnotetext{
44 Friedlander, Pirkê, 219.

45 Friedlander, Pirkê, 223-230.

46 As explained by Warren Baker and Eugene E. Carpenter (The Complete Word Study Dictionary, 1119), this verb means, among others: to bow down, to prostrate oneself, to crouch, to fall down, to humbly beseech, to do reverence, to worship. The primary meaning is "to bow down." It is used to indicate bowing before a monarch or a superior and paying homage to him/her. In the Hebrew Bible it has been used, for example in the Psalms to describe the peculiarity of one's attitude towards God.
} 
1) God tells Abraham to leave his homeland to become a stranger in the land of Canaan;

2) Upon arrival in Canaan, Abraham and his tribe experience famine that forces them to leave for Egypt;

3) The Egyptians seize Abraham's wife, Sarah, and bring her to Pharaoh;

4) Abraham faces incredible odds in the battle against the kings;

5) Subsequently, after not being able to have children with Sarah, he decides to marry Hagar;

6) Abraham is ordered by God to circumcise himself at an advanced age;

7) The king of Gerar, Abimelech, captures Sarah, intending to take her for himself;

8) God orders Abraham to send Hagar away together with a child he had with her;

9) In consequence of expulsion of Hagar, Abraham's son, Ishmael, becomes estranged;

10) God commands Abraham to sacrifice Isaac upon an altar.

On the other hand, as already mentioned, Rashi, fully following Pirqe R. El., includes on the list of trials certain events which are recorded only in the midrashim and enumerates the following trials:

1) Abraham's hiding in an underground cave for thirteen years in Ur of the Chaldees, when the king Nimrod sought to kill him;

2) Nimrod casts Abraham into a fiery furnace for not worshipping idols (b. Erub. 53a, b. Pesah. 118a, Gen. Rab. 38:13);

3) Abraham receives the command to leave his homeland and family (Gen 12:1);

4) Experiencing famine in Israel which began as soon as Abraham arrived there (Gen 12:10);

5) Taking Sarah by the Egyptians at the order of Pharaoh (Gen 12:14-15);

6) Capturing Abraham's nephew Lot in the war of the four kings against the five, as a result of which Abraham went to war to rescue him (Gen 14:1-16);

7) God's foretelling that Abraham's descendants would be enslaved and oppressed (Gen 15:13-16);

8) Circumcision of Abraham and his son at the age of ninety-nine (Gen 17:24);

9) Expelling Ishmael and Hagar;

10) The Akedah.

Rabbi Ovadiah of Bartinura's list of Abraham's ten trials is similar to Rashi's list; however, he omits the thirteen years spent hiding from Nimrod, and includes the Abimelech's abduction of his wife (Gen 20:1-14). Rabbi Yonah of Geronah, as previously mentioned, is the only commentator (similarly to $J u b$.) who does not list the Akedah as the final trial and indicates the death of Sarah, and the purchase of a burial plot for her (Gen 23) as the last trial. 
We can summarize the issues discussed, including selected events regarded as trials and their order:

\begin{tabular}{|c|c|c|c|}
\hline & Pirqe deRabbi Eliezer/ Rashi & Book of Jubilees & Maimonides \\
\hline 1. & $\begin{array}{l}\text { Saving Abraham from death } \\
\text { ordered by Nimrod by hiding in } \\
\text { the cave }\end{array}$ & & Lech lecha \\
\hline 2. & $\begin{array}{l}\text { Imprisonment, casting into } \\
\text { furnace and salvation }\end{array}$ & & $\begin{array}{l}\text { Famine in Canaan and depart- } \\
\text { ing to Egypt }\end{array}$ \\
\hline 3. & Lech lecha & Lech lecha & Taking Sarah to Pharaoh \\
\hline 4. & $\begin{array}{l}\text { Famine in Canaan and depart- } \\
\text { ing to Egypt }\end{array}$ & $\begin{array}{l}\text { Famine in Canaan and depart- } \\
\text { ing to Egypt }\end{array}$ & War with the kings \\
\hline 5. & Sarah being taken to Pharaoh & $\begin{array}{l}\text { Victory and wealth obtained } \\
\text { from the kings }\end{array}$ & Marriage with Hagar \\
\hline 6. & $\begin{array}{l}\text { Capture of Lot, war with } \\
\text { the kings and victory over them }\end{array}$ & Sarah being taken to Pharaoh & Circumcision \\
\hline 7. & $\begin{array}{l}\text { Covenant of the Parts (Brit Bein } \\
\text { HaBetharim) }\end{array}$ & Circumcision & Taking Sarah by Abimelech \\
\hline 8. & Brit Milah & Expelling Hagar and Ishmael & $\begin{array}{l}\text { God's order to send Hagar away } \\
\text { with her son }\end{array}$ \\
\hline 9. & Expulsion of Hagar and Ishmael & Akedah & Expelling Hagar and Ishmael \\
\hline 10. & Akedah & Death of Sarah & Akedah \\
\hline
\end{tabular}

\subsection{Understanding the Trials in Accordance with Gen. Rab.}

One of the key works to understand how the rabbis perceived the trials God put Abraham to is the Great Midrash (Midrash HaGadol) to the Book of Genesis Bereshit Rabbah. In Gen. Rab. 32,3 the unknown author quotes Psalm 11:5 and explains that:

"The Lord trieth the righteous; but the wicked and him that loveth violence His soul hateth" (Ps. XI, 5). R. Jonathan said: A potter does not test defective vessels, because he cannot give them a single blow without breaking them. Similarly the Holy One, blessed be $\mathrm{He}$, does not test the wicked but only the righteous: thus, "The Lord trieth the righteous" R. Jose b. R. Hanina said: When a flax worker knows that his flax is of good quality, the more he beats it the more it improves and the more it glistens; but if it is of inferior quality, he cannot give it one knock without its splitting. Similarly, the Lord does not test the wicked but only the righteous, as it says, "The Lord trieth the righteous". R. Eleazar said: When a man possesses two cows, one strong and the other feeble, upon which does he 
put the yoke? Surely upon the strong one. Similarly, the Lord tests none but the righteous: hence, "The Lord trieth the righteous". ${ }^{47}$

Based on the text of Gen. Rab., we can conclude that God, until the appearance of Abraham, could not find among all descendants of Shem any person who would provide him with the assurance of fulfilling his intentions.

Gen. Rab. does not describe all the trials but focuses only on two of them, where lech lecha (Gen 12:1) has not been precisely described as the "first" - the order of appearance of this event in Abraham's life has not been prejudged, still they described it in the commentary as "a trial" (Gen. Rab. 39,8.7). However, the last trial regarding Akedah was undoubtedly indicated directly by the rabbis in the Gen. Rab. as the "tenth" (Gen. Rab. 54,1).

According to the rabbis the commandment "go (forth)" contained in Gen 12:1 regarded stepping into the first trial; similarly, the last order "go" in Gen 22,1 (concerning the binding of Isaac) was the command to step into the last one. Abraham never hesitated and that is why God chose him as the Forefather of the future nation of Israel and of the whole world (Gen. Rab. 39,1). ${ }^{48}$

Customarily in Abraham's times, the care of parents was the duty of the eldest son. When Abraham left to Canaan, his parents were still alive - Terah was 130 and lived thereafter for 75 more years (Gen 1:32). Abraham, even as the God's chosen one could not just go away and abandon his parents as it would be contrary to the then-customs. Rabbis in the Gen. Rab. appropriately explained this issue. Gen. Rab. shows the fervent discussion of rabbis, who stress the unique righteousness of Abraham in comparison to other inhabitants of his home land. The rabbis explain the relationship between Terah and Abraham in particular way, claiming that Terah was actually „dead while alive."

„But first you may learn that the wicked [Terah], even during their lifetime, are called dead" (Gen. Rab. 39,7.3). ${ }^{49}$ This, in the rabbis' view, exempted Abraham from the obligation of care for parents, as according to their interpretation, those who do not observe the God's Law, are dead while alive and therefore the descendants do not have to care for them - they are released from such a moral duty. God comforted Abraham and assured him that the Patriarch would be free to go and leave his parents without the risk of being misjudged (Gen. Rab. 38,12). Rabbi Abba bar Kahana explained that:

Whoever has his name thus repeated has a portion in this world and in the World to Come. They raised an objection to him: But it is written, NOW THESE ARE THE

\footnotetext{
47 Freedman - Simon, “The Midrash," 268; see also: Scherman - Zlotowitz, Midrash Rabbah, I, $32 \S 3.3$.

48 Freedman - Simon, "The Midrash," 312; see also: Scherman - Zlotowitz, Midrash Rabbah, II, 39 \$1.1.

49 Freedman - Simon, "The Midrash," 314.
} 
GENERATIONS OF TERAH. TERAH BEGOT ABRAM, etc.? That too does not disprove it, replied he, for what is the meaning of, But thou [Abraham] shalt go to thy fathers in peace (ib. XV, 15)? He [God] informed him that his father had a portion in the World to Come; Thou shalt be buried in a good old age (ib.): He informed him that Ishmael would repent in his own days. (Gen. Rab. 38,12). ${ }^{50}$

An additional commentary to Gen 22:15-17 can also be found in Gen. Rab. $(56,11)$, where God spoke to Abraham with the mouth of the Angel of the Lord:

By myself have I sworn, saith the LORD, for because thou hast done this thing, and hast not withheld thy son, thine only son That in blessing I will bless thee, and in multiplying I will multiply thy seed as the stars of the heaven, and as the sand which is upon the sea shore; and thy seed shall possess the gate of his enemies. ${ }^{51}$

Gen. Rab. $(56,11)$ also gives an account of Abraham's response, which may sound very surprising. Abraham begs the Angel that this trial shall be the last one and that he is no more put on further trials: "He had begged Him [Angel of the Lord]: 'Swear to me not to try me again henceforth, nor my son Isaac. [...]" This plea indicates that - as it was later interpreted by Samuel ben Meir (Rashbam) - this trial was also God's punishment. In light of the account in Gen. Rab., Abraham seriously struggled with this trial. ${ }^{52}$ According to this interpretation the tenth trial was God's punishment - intended "pain of infliction" for the commitment Abraham made to king Abimelech (Gen 21:23-24) ${ }^{53}$. Abraham swore to the king that neither him nor his descendants would ever be expelled from the land of Canaan. Meanwhile, God (Gen 15:7) swore and promised the entire land of Canaan to Abraham and his descendants, thus the covenant between Abraham and Abimelech was contrary to the wish of the Highest: Abraham and his descendants were supposed to receive the "whole" of Canaan and not only its part. In this context, Rashbam analyses the word nisah from Exod 17:7 - the verb, which, as he indicates, in this context may signify not only a trial and/or a test, but also despair - the feeling Abraham experienced very strongly offering his son Isaac for a burnt sacrifice. The loss of a son meant the lack of a heir and death of the family. The Eternal almost immediately punished Abraham for his thoughtless action. Abraham humbly accepted the "death sentence" for Isaac, meaning the end of succession. By that for the last time - in the tenth trial - he proved his allegiance and faith in God.

\footnotetext{
Freedman - Simon, “The Midrash," 309.

Freedman - Simon, "The Midrash," 500.

Freedman - Simon, "The Midrash," 500.

Drazin - Wagner, Onkelos, 133.
} 
Discussing these questions the rabbis tried to explain the reasons for each trial, indicating in particular the peculiarities of Abraham's character and his special bond with the Eternal.

\section{Conclusions}

The accounts of Abraham's history as a series of ten trials has existed since the very beginning of the known interpretations of the Book of Genesis. The oldest sources, such as Jub. and $m$. Pirqe Abot, include mentions of the trials. Such a presentation of the Patriarch's figure was intended to provide theological foundations for God's election of this particular man (and none other). As described above, there is no single list of Abraham's trials, and the rabbinical sources vary as to the choice of events determined as trials and to their order. Their concepts are based on the text of the Hebrew Bible, but also on other sources and traditions.

What is common for all these considerations, it is that the history of Abraham, according to the rabbis has been God's relentless, continuous redemptive act aimed at saving and liberating the Jews throughout the centuries. The idea of the covenant with God (brit) starting from Abraham Avinu, is the foundation, the cornerstone of Judaism: Israel entered into a covenant with God - an agreement comprising of rights and duties of both parties. Abraham had to be put to ten trials of his faith in order to prove his worthiness to receive the gift of God's eternal covenant.

According to Maimonides, the statement "God tried Abraham" does not mean that God tested him, but he made of Abraham an example of the extreme boundaries of love and fear with respect to God. "For now I know that thou fearest God" (Gen 22:12) means that God announced to all mankind how far must a human being go fearing the Almighty. As said by Nahmanides, the Akedah as the last trial focuses on reconciling the pre-knowledge of God with man's free will. God knew how Abraham would behave, but from Abraham's point of view the trial was real; the Patriarch must have been put to trial and after standing it be awarded not only for his potential willingness to obedience, but for his true submission to God.

The only purpose of all of Abraham's experiences was to teach people how to act and how to believe. The particular events of Abraham's life should be examples and guidance. Through the trials the Almighty makes sure that every man is aware of the fact that submission and obedience would guide him to God: He is then "the LORD that doth sanctify" (Exod 31:13). God intends to illustrate his people how strong their faith to the truth of God's Word is and how well they have 
understood and accepted the true Nature of God. Knowing and remembering the trials should remove God's anger and provide compassion and love. ${ }^{54}$

The rabbinical approach to the issue of Abraham's trials has been known only to limited audiences of scholars and is not very popular out of Judaism, although Christians often refer to Abraham as the Patriarch and Father in faith. The provided commentaries, selected for the purpose of this study, refer to old rabbinic literature. Of particular importance for the studies on Abraham's trials are such rabbinic works as Gen. Rab., Pirqe R. El. and Jub. So there is a rich and comprehensive variety of sources, which enable in-depth studies of every single trial and analysis of its outcome and significance for future generations. The omission of the Jewish sources impoverishes possible results and limits the multidimensionality of Abraham's life and experiences. The use of the Jewish sources helps to better understand Abraham's life and recognize his immense importance in the history of salvation.

The overview of Abraham's ten trials clearly testifies to the existence of a rich, extensive rabbinic literature and of significant Jewish theological traditions in this respect, which should not be disregarded. Taking into account the contemporary commentaries, one may state that there is willingness and need for studies of rabbinical works. An evident encouragement to pursue such studies has been expressed, for example, by Joseph Cardinal Ratzinger in his preface to the document prepared by the Pontifical Biblical Commission, The Jewish People and Their Sacred Scriptures in the Christian Bible (2001), where he argues that "Christians can learn a great deal from a Jewish exegesis practiced for more than 2000 years." ${ }^{55}$ The studies of the rabbinic works may help to develop our knowledge of exegetical methods and the theology of the biblical texts and will allow us to discover their impact on contemporary people's lives. Finally, they may open a new dimension to understanding Abraham's life and thus giving it farther perspectives.

54 An example is Zichronot prayer at Jewish New Year (Rosh Hashana), where there is the following plea addressed to God for Him to remember the Akedah: "Remember on our behalf, O Lord our God the covenant and the love and the oath that you swore to Abraham our father on Mt. Moriah. Let it appear before you, this Akedah, that Abraham bound Isaac his son on the altar, and he suppressed his compassion in order to do your will with a complete heart. Therefore your compassion should suppress your anger against us. Through your goodness may your anger be removed from your city and your inheritance" - Zichronot of Rosh Hashanah Musaf, quoted in Milgrom, Binding, 70-77.

The Pontifical Biblical Commission, The Jewish People. 


\section{Bibliography}

Baker, W. - Carpenter, E.E. (eds.), The Complete Word Study Dictionary. Old Testament (Chattanooga, TN: AMG Publishers 2003).

Drazin, I. - Wagner, S.M., Onkelos on the Torah. Understanding the Bible Text (Jerusalem: Gefen 2012) I.

Freedman, H. - Simon, M., “The Midrash Rabbah," Soncino Classics Collection DVD (Judaic Classics Library. Davka Corporation; New York: Soncino Press 2009) [electronic publication].

Friedlander, G. (trans., ed.), Pirkê de Rabbi Eliezer (London: Kegan Paul, Trench, Trübner 1916).

Ginzberg, L., Legends of the Jews (Philadelphia, PA: Jewish Publication Society 2003) I.

Goldin, J., (trans., ed.), The Fathers According to Rabbi Nathan (New Haven, CT: Yale University Press 1955).

Herford, R.T., "Pirkē Aboth: The Sayings of the Fathers," The Apocrypha and Pseudepigrapha of the Old Testament in English with Introductions and Critical and Explanatory Notes to the Several Books. II. The Pseudepigrapha of the Old Testament (ed. R.H. Charles) (Oxford: Clarendon Press 1913) 686-714.

Jacobson, H., A Commentary on Pseudo-Philo's Liber Antiquitatum Biblicarum with Latin Text and English Translation (Leiden: Brill 1996) I.

Leibowitz, N., New Studies in Bereshit (Genesis) in the Context of Ancient and Modern Jewish Bible Commentary (Jerusalem: Maor Wallach Press 2010).

Lumpkin, J. (ed.), The Encyclopedia of Lost and Rejected Scriptures (Blountsville, AL: Fifth Estate 2010).

Mack, H., The Aggadic Midrash Literature (Tel-Aviv: MOD Books 1989).

Milgrom, J., The Binding of Isaac. The Akedah, a Primary Symbol in Jewish Thought and Art (Berkeley, CA: Bibal Press 1988).

Noegel, S., "Abraham's Ten Trials and Biblical Literary Convention," Jewish Bible Quarterly 21 (2003) 73-83.

Pecaric, S. (ed.), Sidur Pardes Lauder (Kraków: Stowarzyszenie Pardes - The Ronald S. Lauder Foundation 2005).

The Pontifical Biblical Commission, The Jewish People and Their Sacred Scriptures in the Christian Bible (Città del Vaticano: Libreria Editrice Vaticana 2002).

Saldarini, A.J., The Fathers According to Rabbi Nathan (Abot de Rabbi Nathan) Version B (Leiden: Brill 1975).

Scherman, N. - Zlotowitz, M. (eds.), Kleinman Edition Midrash Rabbah. I. Bereishis - Noah. II. Lech Lecha - Toldos (ArtScroll Series; New York: Mesorah Publications 2014).

Skolnik, F. (ed.), Encyclopaedia Judaica (Farmington Hills, MI: Gale 2007) I-XXII (= EncJud).

Stemberger, G., Introduction to the Talmud and Midrash (Edinburgh: Clark 1996).

VanderKam, J.C., Jubilees 1 \& 2. A Commentary on the Book of Jubilees. I. Chapters 1-21. II. Chapters 1-50 (Hermeneia. A Critical and Historical Commentary on the Bible; Minneapolis, MN: Fortress 2018). 